\title{
Women Farmers' Perceived Impact and Acceptability of the Ongoing Agrcultural Development Programmes in Enugu State
}

Dimelu M. U, E. M Igbokwe and A. U Obieri

Department of Agricultural Extension

University of Nigeria, Nsukka

\begin{abstract}
The study appraised the National Special Programme for Food Security (NSPFS), Root and Tuber Expansion Programme (RTEP) and Presidential Initiative on Increased Cassava Production, Processing and Export (PICPPE) in Enugu State using women beneficiaries. Data were collected from 270 randomly selected women by use of interview schedule. Simple descriptive statistics and analysis of variance (ANOVA) were used for data analysis. The programmes had similar and complementary baseline conditions. The women expressed acceptance of the baseline condition, but NSPFS baseline condition was more acceptable than that of RTEP and PICPPE with total mean scores of 4.4, 4.1 and 2.7, respectively. There was no significant difference in the impact of the programmes across the zones. Generally, the programmes were gender sensitive, but the popular poor access of women to production resources calls for greater investment on capacity building and sustained institutional support. Also given the market driven agricultural development trends across the globe, development intervention should essentially incorporate appropriate policy, legislative, and information system for sustainability and optimum impact.
\end{abstract}

\section{INTRODUCTION}

Women constitute half of the world's population and about 565 million of them reside in rural areas in developing countries where they perform increasingly indispensable roles in agricultural and national development (Akpabio, 2005). Studies have shown that rural women farmers perform about $70 \%$ or more of all agricultural production activities, $100 \%$ of food processing and utilization activities and over $50 \%$ of storage and marketing operations (Kawani and Pernia, 2002). According to Saito (1992) women tend to contribute more towards agricultural production which constitutes an important aspect of national development. Women put in more hours in agricultural and non-agricultural activities than men.

Women ensure household food security because they have greater influence on household food expenditure, caloric intake and anthropometric indicators. Furthermore, they allocate their time and resources to ensure that children and the elderly are adequately fed within available means, and pay adequate attention to meeting the physical, mental and social needs of entire 


\section{Journal of Agricultural Extension}

Vol. 13 (1) June, 2009

household members. As household shock absorbers, during times of economic and physical hardship, women expand their already highly stretched and undervalued working hours, and may even reduce their nutritional status to enhance that of the family (Obasi, 2005). Above all, women make greater impact in the socio-economic and political development of their societies as groups rather than as individuals. The groups include co-operative societies, women religious group associations, women age grades, women wing of development or town unions, "umuadas" etc. These groups are useful to mobilize women for the realization of development programmes in and even beyond their communities. Thus, women's roles in all these areas contribute a major boost to economic development in rural communities. Their products and services swell up the available stock of goods (i.e. gross domestic products) needed by both rural and urban populations.

This notwithstanding, empirical findings reveal that although women perform nearly two-third of the world's work, they receive only one-tenth of the world's income and own less than onehundredth of the world's property (World Bank, 2002). With reference to agriculture, women farmers receive less than 10 percent of total credit allocated to farmers and only one percent of total credit allocated to agriculture. Also, because of the erroneous assumption that men and not women make the key farm management decisions, women receive less than 5 percent of extension service worldwide, a bulk of which is focused on domestic roles like childcare and nutrition. It has also been revealed that less than 3 percent of extension officials are women, and that in the whole United Nations system, only 4 percent of programmes benefit women (World Bank, 2002). In essence, women's priorities are rarely reflected in agricultural or national development research or policies.

Nevertheless, the ability of women to contribute to the development process depends on the extent to which they participate in the decision-making process at all levels. Unfortunately, they are constrained by systemic gender biases in form of customs, beliefs and attitudes that confine them to the domestic sphere and bars them from household and other levels of decision making. It also restricts their access to resources such as land, water, credit, productive agroinput, improved technology, employment, education, information and extension training and services that would have enhanced their productive capacity. For instance, during the World Bank mission to the southeast agricultural development programmes (ADPs), it was observed that the activities of women in the field of agriculture were not adequately covered by the extension services, in spite of their individual and collective effort. Very little improved agricultural technologies were reaching the women folk resulting in their ineffective utilization of farm production and related technologies. The World Bank (2002) reported that marginalization of women in general and rural women in particular were tantamount to stifling their potentials and denying the nation or rural communities the rewards inherent in such potentials.

Following the above scenario, the subject of 'gender' with particular reference to women has become a recurrent issue at local, national and international fora. This increasing concern on women in the context of national agricultural development largely anchors on some widely held views that the full potentials of women have hardly been developed and tapped in many societies in the world and that women have over the centuries remained victims of general trends across the globe which relegate women in the scheme of things.

On the other hand, the enhancement of the status of women over the decades and across the globe has been facilitated by the forces of industrialization with the attendant bureaucratic values and norms in organizational production, political democratization ,which has degenderised modern political processes, and feminist movement or women liberation struggles which have been given greater fillip by the United Nations proclamation of the 1975 as international year for women and 1975-1985 "the decade for women". The aims of these 
proclamations were to draw world attentions to the vast untapped potential of women especially in developing societies where gender-discriminatory traditions and customs abound and to devise means of developing and harnessing these for socio-economic development. In Nigeria, some national agencies had zeroed their development programmes on women;for example, Mrs. Maryam Babangida's Better Life Programme for Rural Women (BLPRW); Mrs. Maryam Abacha's Family Economic Advancement Programme (FEAP) and others.

Currently, many special development programmes are going on across the state of the nation. These programmes include: National Fadama Development Programme (1992), National Economic Empowerment and Development Strategy (2001), National Programme for Food Security (NPFS) (2001), Root and Tuber Expansion Programme (RTEP) (2002), and Presidential Initiative on Increased Cassava Production, Processing, and Export (PICPPE) (2004). These programmes were designed to transform the nation particularly rural areas economically, socially and infrastructurally. However, the extent to which these programmes reflected the needs of women farmers are not certain.

Specifically, the study was conducted to appraise 3 development programmes namely NSPFS, RTEP and PICPPE.NSPFS was launched in 2001 by the government of the federation in partnership with International Fund for Agricultural Development( IFAD) as the donor agency. The programme aimed to attain food security and eliminate rural poverty in the country. In the same way, RTEP is an (IFAD) and World Bank supported programme designed to increase smallholder production of cassava, yams, potatoes and cocoyam as well as their end products as means of enhancing national food self-reliance and improving household food security and increasing income of rural households. Similarly, PICPPE was launched in 2004 by President Obasanjo specifically to reduce rural poverty, enhance food security and increase Nigeria foreign earnings. However, despite the laudable objectives and operational mechanisms of these programmes, relevant questions that arise are; how do rural women who dominate the labour force of the agricultural sector perceive these development programmes? How acceptable are the baseline conditions to the rural women, in terms of the objectives, technological packages, capacity building, target crops and financial assistance; and what is the perceived impact of the programmes on the women beneficiaries? The study was therefore designed to appraise the programmes from gender perspective. Specifically, the study sought to;

- compare the baseline conditions of the programmes;

- assess the acceptability of the programmes base-line conditions by the women beneficiaries; and

- $\quad$ assess the perceived impact of the programmes on the beneficiaries.

\section{METHODOLOGY}

The study was carried out in Enugu State.Enugu State is made up of 17 local government areas(LGAs) and 3 agricultural zones namely Enugu West, Enugu East and Enugu North. Nine LGAs where the three programmes under study are on-going were purposively selected from the agricultural zones. National Special Programme on Food Security was cited only in three LGAs. The three LGAs are; Aninri (Enugu West), Nkanu East (Enugu East), Uzo-Uwani (Enugu North). RTEP was redesigned and implemented in 5 LGAs. The benefiting LGAs are Awgu, Enugu East, Igbo-Etiti, Nsukka and Oji-River. Three LGAs were randomly selected namely Enugu East (Enugu East Zone), Awgu (Enugu West Zone), and Nsukka (Enugu North zone). 
Journal of Agricultural Extension

Vol. 13 (1) June, 2009

PICPPE is implemented in all the LGAs in the state. Three LGAs, one from each zone were randomly selected. They included Enugu South (Enugu East), Oji-River (Enugu West), Igbo Etiti (Enugu North). On the whole, 9 LGAs constituted the sample. A list of participating farmers was accessed and 30 women farmers were randomly selected from each programme in each LGA selected. A total of 270 respondents were used (Table 1).

TABLE 1: Sample selection

\begin{tabular}{llllll}
\hline Agricultural zones & Local governments & NSPFS & RTEP & PICPPE & Total \\
\hline Enugu East & Enugu East & - & 30 & - & 30 \\
& Enugu South & - & - & 30 & 30 \\
& Nkanu East & 30 & - & - & 30 \\
Enugu West & Oji-River & - & - & 30 & 30 \\
& Aninri & 30 & - & - & 30 \\
& Awgu & - & 30 & - & 30 \\
Enugu North & Igbo-Etiti & - & - & 30 & 30 \\
& Nsukka & - & 30 & - & 30 \\
& Uzo Uwani & 30 & - & - & 30 \\
\hline Total & 9 LGAs & 90 & 90 & 90 & 270 \\
\hline
\end{tabular}

Data were collected using interview schedule. Both Secondary and primary data were used. Secondary data such as reports, implementation document and others were used to achieve the first objective. Primary data measured level of acceptability and perceived impact.To measure the acceptability of the programmes( objective 2), the respondents were asked to indicate level of acceptance of the objectives, targeted beneficiaries/crops, financial resources and others on a four point Likert type scale of "to a great extent" (5), "to some extent" (4), "to a little extent" (3), "to very little extent" (2), and"to no extent" (1). Objective 3 ( impact of the programmes) was measured by asking the respondent to indicate on a five point Likert type scale of "strongly agree" (5), "agree" (4), "undecided" (3), "disagree" (2), "strongly disagree" (1). Mean score were used to analyse objectives 2 . Mean scores $\geq 3$ was regarded as acceptance, while objective 3 was analysed with percentage. The summed percentage of the responses was used. One way analysis of variance was used to determine difference in perceived impact of the programmes .

\section{RESULTS AND DISCUSSION}

\section{Comparison of Baseline Conditions of NSPSF, RTEP and PICPPE}

Programme objectives: Table 2 shows that the three programmes (NSPSF, RTEP and PICPPE) have similar and related objectives. Generally, the programmes aimed to enhance farmers' income and food security on a sustainable basis, reduce poverty and increase foreign earning. The problems of poverty and food security are closely related and have steadily 
increased in Nigeria. According to UNDP in its Human Development Report(2005), Nigeria is ranked among the world's $20^{\text {th }}$ least developed countries and $29^{\text {th }}$ poorest countries of the world. Also by the November 1999 World Food Summit, Nigeria was ranked as one of the 82-lowincome food deficit countries. Therefore, addressing the issues of poverty and food insecurity particularly among the rural populace is both timely and relevant. However, making the country food secured should not be treated in isolation to other indexes of living standard. Obamiro, Doppler and Kormawa (2003) suggested that efforts geared towards achieving food security should also address other areas of human and infrastructural development. Besides, poverty as a function of several factors both social, political, economic and infrastructural calls for an inclusive and holistic approach.

Target beneficiaries/crops: The three programmes targeted small-scale farmers who produce mostly root and tuber crops (Table 2). Only NSPFS included livestock, fisheries, agro-forestry, health and nutrition education including HIVIAIDS awareness campaign. The selection criteria could be attributed to the fact that root and tuber crops which are cheap energy foods, contributing about $53 \%$ of caloric intake are mostly cultivated by people in rural areas (Azogu, 2006). Moreover, cassava appeared common in all the programmes probably because of its high adaptability to marginal soils and the diversity of products that could be derived from it. Besides, it is also rich in carbohydrate, resistant to pest and diseases and could be cropped throughout the year.

Concentration of efforts on small-scale farmers is statistically appropriate because they constitute the larger proportion of labour force in agriculture. Above all, Adegeye and Diltoh (1985) observed that small-scale farmers are worse in terms of poverty level because they produce the bulk of the food and fibre for the nation and yet lack access to improved farm inputs, appropriate technology, credit facilities and social services.

Selection criteria: NSPFS selected areas with highly under developed agricultural potentials, large population with low rural livelihood status. Three sites were selected in each state during the pilot phase for maximum concentration, but extra three sites were added in the expansion phase. This might be due to observed impact, and adaptability of the programme to the sociocultural environment of beneficiaries.

Similarly RTEP in the first tri-terms selected small-scale farmers who cultivated less than three hectares of root and tubers crops in the 26 states, but in the second tri term, it was redesigned to concentrate on three Local Government Areas. Reasons could include unrealistic scope, low impact, inadequate funding, human resource and low adaptability of the programme in some localities.

On the other hand, PICPPE focused on small-scale farmers in all the agro-ecological zones of Nigeria who either produce, process, market or utilize cassava and its products. Obviously, PICPPE selection criteria were not based on comparative advantage, agricultural potentials and possibly available human and material resources. Although cassava is cultivated virtually in every agro-ecological zone, but some areas have greater potential advantage, more rewarding in terms of impact. Moreover, the implementation, monitory and evaluation, management of the programme may be more problematic. Also there is high chances of directing interventions to the wrong beneficiaries and areas that are less rewarding. However, on the overall there is a significant shift in traditional top-down and linear approach that characterised past development efforts in the country. 
Journal of Agricultural Extension

Vol. 13 (1) June, 2009

TABLE 2: Comparison of NSPFS, RTEP and PICPPE according to baseline conditions

\begin{tabular}{|c|c|c|c|}
\hline Variables & NSPFS & RTEP & PICPPE \\
\hline $\begin{array}{l}\text { Programmes } \\
\text { objectives }\end{array}$ & $\begin{array}{l}\text { Assisting farmers in achieving } \\
\text { their potentials for increasing } \\
\text { output and productivity and } \\
\text { consequently their incomes on } \\
\text { sustainable basis, strengthen } \\
\text { the effectiveness of research } \\
\text { and extension services in } \\
\text { bringing technology and new } \\
\text { farming practices developed } \\
\text { by research institutes. }\end{array}$ & $\begin{array}{l}\text { Increase } \\
\text { smallholder } \\
\text { production of } \\
\text { cassava, yams, } \\
\text { cocoyam and } \\
\text { potatoes. Enhance } \\
\text { food security. } \\
\text { Increase income of } \\
\text { rural household. }\end{array}$ & $\begin{array}{l}\text { Enhance food } \\
\text { security increase } \\
\text { foreign incomes of } \\
\text { cassava producers, } \\
\text { processors and } \\
\text { marketers. }\end{array}$ \\
\hline Selection criteria & $\begin{array}{l}\text { Areas with high under- } \\
\text { developed agric potentials, } \\
\text { large farming population with } \\
\text { low rural livelihood status. }\end{array}$ & $\begin{array}{l}\text { Small-scale } \\
\text { producers } \\
\text { cassava, yams, } \\
\text { cocoyam and } \\
\text { potatoes. } 5 \text { LGAs/ } \\
\text { State }\end{array}$ & $\begin{array}{l}\text { Cassava producing } \\
\text { farmers in all the } \\
\text { agro-ecological zone } \\
\text { of Nigeria. }\end{array}$ \\
\hline $\begin{array}{l}\text { Targeted } \\
\text { beneficiaries }\end{array}$ & $\begin{array}{l}\text { Crops and livestock small- } \\
\text { scale farmers in Nigeria. }\end{array}$ & $\begin{array}{l}\text { Small-scale root } \\
\text { and tuber } \\
\text { producers in } \\
\text { southern and } \\
\text { middle-belt states } \\
\text { of Nigeria. }\end{array}$ & $\begin{array}{l}\text { Small-scale cassava } \\
\text { producers, } \\
\text { processors, bakers } \\
\text { and caterers in the } \\
\text { agro-ecological zone } \\
\text { of Nigeria. }\end{array}$ \\
\hline $\begin{array}{l}\text { Targeted crops and } \\
\text { livestock }\end{array}$ & $\begin{array}{l}\text { Cassava, rice, cocoyam, yam, } \\
\text { leafy vegetables, poultry, } \\
\text { sheep and goats and swine } \\
\text { production. }\end{array}$ & $\begin{array}{l}\text { Yam, cocoyam, } \\
\text { cassava and } \\
\text { potatoes. }\end{array}$ & Cassava only. \\
\hline $\begin{array}{l}\text { Executing/implement } \\
\text { ing agencies }\end{array}$ & FMARD, PCU, ADP, NRCRI & $\begin{array}{l}\text { FMARD, PCU, } \\
\text { ADP, NRCRI, IITA }\end{array}$ & $\begin{array}{l}\text { FMARD, ADP, } \\
\text { NRCRI and IITA }\end{array}$ \\
\hline $\begin{array}{l}\text { Capacity building of } \\
\text { farmers and } \\
\text { facilitators }\end{array}$ & Workshop & Workshop & Workshop \\
\hline $\begin{array}{l}\text { Technological } \\
\text { packages }\end{array}$ & $\begin{array}{l}\text { Use of improved crop varieties } \\
\text { and livestock breeds, improved } \\
\text { management system }\end{array}$ & $\begin{array}{l}\text { Use of improved } \\
\text { varieties, improved } \\
\text { storage, } \\
\text { processing, pest } \\
\text { and disease } \\
\text { control } \\
\text { technologies }\end{array}$ & $\begin{array}{l}\text { Use of improved } \\
\text { varieties, improved } \\
\text { cropping system } \\
\text { modern agro- } \\
\text { processing, products } \\
\text { utilization and } \\
\text { marketing activities. }\end{array}$ \\
\hline Financial assistance & $\begin{array}{l}\text { Agro-inputs through ADPs and } \\
\text { soft loan through Banks. }\end{array}$ & $\begin{array}{l}\text { Agro-inputs and } \\
\text { agro-processing } \\
\text { machines through } \\
\text { IITA and ADPs }\end{array}$ & $\begin{array}{l}\text { Agro-inputs and agro- } \\
\text { processing machines } \\
\text { through IITA and } \\
\text { ADPs }\end{array}$ \\
\hline Funding agencies & FAO, FGN and States & $\begin{array}{l}\text { IFAD, FGN and } \\
\text { States }\end{array}$ & $\begin{array}{l}\text { World Bank, FGN and } \\
\text { States }\end{array}$ \\
\hline $\begin{array}{l}\text { Linkages and } \\
\text { institutions }\end{array}$ & $\begin{array}{l}\text { PICPPE, RTEP, ADPs and } \\
\text { NRCRI }\end{array}$ & $\begin{array}{l}\text { Linked to the IFAD- } \\
\text { Assisted CMP, } \\
\text { NSPFS, ADPs, } \\
\text { NRCRI and IITA }\end{array}$ & $\begin{array}{l}\text { Linked to the IFAD- } \\
\text { Assisted RTEP and } \\
\text { PMCMD, NSPFS, } \\
\text { ADPS, IITA and } \\
\text { NRCRI }\end{array}$ \\
\hline
\end{tabular}




\section{Implementing agencies/Capacity building technological packages}

The implementing agencies of the three programmes were Federal Ministry of Agriculture and Rural Development( FMARD),Project Coordinating Unit (PCU),Agricultural Development Programmes (ADPs),National Root Crop Research(NRCRI) andlnternational Institute of Tropical Agricultural( IITA). Specifically, the FMARD is at the apex of the implementing agencies perhaps because of its pivot role in policy formulation and coordination of agricultural programmes. The use of existing institutions and staff is to an advantage particularly in overcoming initial implementation problems, management of fund and channelling interventions to the right people. However, the absence of education institutions (universities and colleges of agriculture) in research, training and extension outfit leaves a critical gap in the whole process.

\section{Capacity building/Technological packages}

The capacity building of the programmes was through workshops and training. Technological packages were on provision of improved high yielding disease resistant varieties, improved agronomic practices and improvement in processing technologies. The programmes seem to provide little or no innovative marketing strategies. Further enquiries from the beneficiaries revealed that most farmers lost hectares of cassava farms due to lack of market facilities and high cost of transport, and slow adoption of value added products of cassava. Micro and macro economic factors associated with intervention should be equally taken into consideration for maximum output.

\section{Financial assistance/finding agencies}

The financial assistance of NSPFS was both input and soft revolving loan; while that of RTEP and PICPPE were inputs and agro-processing machines. The programmes were donorsponsored but the participation of the federal and state makes the programme financially sustainable. However, the problem, as with past development efforts, has always been instability in government and subsequent changes in policies. The soft revolving loan of NSPFS will no doubt make the programme more acceptable to the farmers. Furthermore it is a surer way of increasing farmer income in a sustainable basis because it encourages diversification of farmers' economy.

\section{Linkage and institutions}

The programmes are linked to research and extension institutions (IITA, NRCRI and ADPs) and past programmes such as IFAD - assisted CMP, PMCMD. Structurally, the programmes seem to be well linked, but the problem is, how strong the linkages are and the mechanisms adopted to facilitate interaction. Often time, linkage strategies and mechanisms are clearly stated, but in practice, they might not be operational or effective due to inherent poor leadership/orientation, inflexibility in management and organizational objectives/mandates existing in the agricultural research and extension system. Linkage in development intervention/programmes is apt to reduce duplication, waste of scarce resources and ensure greater innovative performance in the sector.

\section{Acceptability of Programme Baseline Conditions}

Table 3 shows that the women beneficiaries accepted the objectives of NSPFS (4.5), RTEP (4.2) and PICPPE (3.7). This suggests that the programmes objectives are on the priority needs of the women farmers. It is not surprising because rural women farmers perform about $70 \%$ or more of all agricultural production activities, $100 \%$ of food processing and utilization activities, over $50 \%$ of storage and marketing operations (Kawani and Pevinia, 2002), but have less access to productive resources. They are the most vulnerable and marginalised group in the 
Journal of Agricultural Extension

Vol. 13 (1) June, 2009

society. According to World Bank (2002) it is tantamount to stifling their potentials and denying the nation or rural communities the reward inherent in such potentials.

TABLE 3: Mean distribution of the acceptability of the programmes ' base-line conditions by the women stakeholders

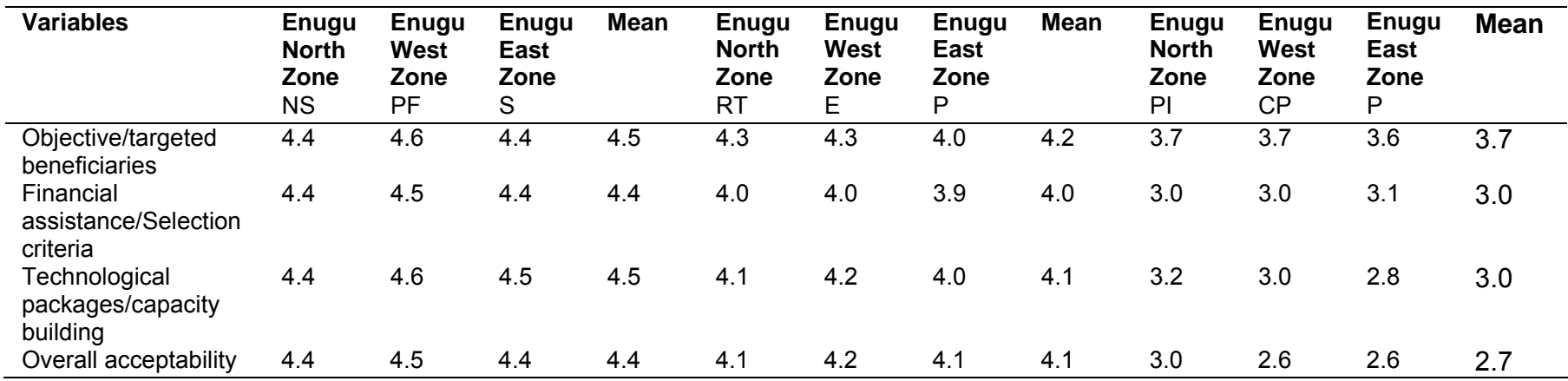

\section{Financial assistance/Selection criteria}

The respondents indicated acceptance of the financial assistance and selection criteria of the programmes. However, NSPFS (4.4) was more acceptable, followed by RTEP (4.0) probably because of the revolving learn accessed by the farmers. Access to credit encourage diversification and enable farmers to weather economic shocks, invest and build up assets. Farmers are able to expand hectarage, access relevant inputs not included in the technological packages. However, the issue of making the programme financially sustainable remains a formidable challenge to planners and policy makers. The concentration of the programmes on carefully selected areas based on some criteria also makes for maximization of relative potentials and benefits of the programmes .

\section{Technological packages/Capacity building}

Data in Table 3 show that the respondents accepted the technological packages/capacity building of NSPFS (4.5), RTEP (4.1) and PICPPE (3.0). However, the mean perception specifically across the zones suggests that PICPPE was least accepted by the respondents. The respondents may not have received much in terms of inputs and training because of the undefined target population and wide coverage of the programme. The positive response suggests that the technological packages were appropriate and gender sensitive. Unlike most past development programmes which were largely influenced by the erroneous assumption that men and not women make the key farm management decisions. Availing women opportunity by these programmes to maximise their potential through training and supply of productive inputs is a great incentive and practice that should be compulsory injected into development programmes.

\section{Perceived Impact of NSPFS, RTEP and PICPPE}

Majority ( $84.0 \%, 74.3 \%$ and $56.5 \%$ ) of the respondents indicated that NSPFS had positive impact at ENZ, EEZ and EWZ respectively (Table 4). About $82 \%$ and $71 \%$ perceived that RTEP had positive impact both at ENZ and EEZ, respectively. Only about $33 \%$ reported positive impact of RTEP at EWZ. Table 4 further shows that PICPPE had positive impact at ENZ $(71.0 \%)$ and EEZ (53.3\%), while at EWZ, only $26.5 \%$ perceived positive impact of the 
programme. Notably, the programmes seem to have less impact in EWZ. Generally, the results suggest that NSPFS had more impact followed by RTEP and PICPPE.

TABLE 4: Perception of NSPFS, RTEP and PICPPE impact by the respondents

\begin{tabular}{lllll}
\hline Programme & ENZ & EWZ & EEZ & $\bar{X}$ \\
\hline NSPFS & 84 & 56.5 & 74.3 & 71.6 \\
RTEP & 81.8 & 32.8 & 70.5 & 61.7 \\
PICPPE & 71 & 26.5 & 53.3 & 50.3 \\
F-value & $72.3^{*}$ & $8.6 \mathrm{~ns}$ & $66^{*}$ & $15.6^{*}$ \\
\hline
\end{tabular}

*Significant at 0.05 level

E.N.Z = Enugu north zone.

E.W.Z = Enugu west zone.

E.E.Z = Enugu east zone.

One way analysis of variance shows non significant difference in the overall perceived impact of the programmes (Table5), but significant difference exists in the zones(FLSDp $\leq 0.05=15.60)$. The variance in perceived impact of the programmes in the zones might be as a result of interaction of several factors such as potentials and comparative advantage of locations, attitude of facilitators, and communities bureaucracy, presence of related intervention possibly from non-governmental organization and others. However, further analysis of detail impact index in terms of social, economic, and infrastructural changes associated with the programmes might generate a different picture.

TABLE 5: Analysis of variance on perceived impact of the projects

\begin{tabular}{lccccc}
\hline $\begin{array}{l}\text { Sourxes of } \\
\text { variation }\end{array}$ & Df & Ss & Ms & f-cal & f-tab \\
\hline Traement(projects) & 2 & 356.2 & 178.2 & $1.25 \mathrm{~ns}$ & 4.46 \\
Error & 2 & 1911.7 & 955.9 & - & 4.46 \\
\hline Total & 4 & 568.6 & 142.2 & 6.72 & \\
\hline
\end{tabular}




\section{Journal of Agricultural Extension}

Vol. 13 (1) June, 2009

\section{CONCLUSION AND RECOMMENDATION}

The objectives of the programme addressed critical issues of poverty and food security with emphasis on the rural farmers, which are both national and global concern. The contents of baseline conditions like target beneficiaries, crops, selection criteria, technological packages and others suggest that these programmes were borne out of experience and empirical data perhaps from past development efforts. The women beneficiaries expressed acceptance of the baseline conditions of the programmes. The programmes were gender sensitive and addressed the priority needs of the women farmers in production, processing and utilization of agricultural outputs. Obviously, the inclusion of revolving loan in NSPSF significantly influenced the respondents' level of acceptance of the programmes. Both programmes had positive impact on the beneficiaries, though with significant difference across the zones. Contrarily to the top-down, linear model adopted in past development programmes, the results show that the programmes employed community-based, participatory and gender mainstreaming approach. Efforts were concentrated on priority and relatively high potential crops and appropriate population (smallscale farmers). Above all, the programmes were linked to each other, past programmes and relevant institutions. Absence of collaboration of programmes was one of the major impediment to past rural development programmes.

From the findings, it is recommended that strategies designed to address poverty and food insecurity should be more inclusive to reduce/eliminate other indexes associated with the phenomenon. Participation of universities and colleges of agriculture is crucial given the pivot role played by these institutions in research, training and extension services. In other words greater active stakeholders participation should be encourage for synergy, complementarity of efforts, appropriate capacity building and sustainability. Moreover, the changing context of the agricultural sector which is increasingly becoming more dynamic requires greater access to credit by the farmers to enhance diversification of the rural economy against economic shocks and natural disaster. Credits facilities should be incorporated into development programmes.

\section{REFERENCES}

Akpabio, I.A. (2005). Women and agricultural development: In Ike N. and Onuewusi, G.C. (eds.) Agricultural Extension and Rural Sociology. SNAAP Press Ltd Enugu, Nigeria.

Azogu, I. (2006). Appropriate processing operations and machinery selection for high quality cassava products. A paper delivered at Benue State ADP during a collaborative RTEP/NCAM Workshop $17^{\text {th }}$ and $18^{\text {th }}$.

Kawani, N. and Pernia, E.M. (2002). What is pro-poor growth? Asian Development Review: Vol. 18, No. 1, pp. 1-10.

NMTIP Draft (2004). National medium-term investment programme in the new partnership for African agricultural development programme.

Obamiro, E.O., Doppler, W. Kormawa, P.M. (2003). Pillars of Food Security in Rural Areas of Nigeria. Food Africa, Internet Forum $31^{\text {st }}$ March $-11^{\text {th }}$ April, 2003. Internet paper accepted for Food Security Theme.

http://foodafrica.nri.org/security/internetpapers/ObamiroEunice.pdf.

Obasi, O.O. (2005). Women in rural development: The Nigerian experience: In: Ike, N. and Onuewusi, G.C. (eds.) Agricultural Extension and Rural Sociology. SNAPP Press Ltd. Enugu, Nigeria. 


\section{Journal of Agricultural Extension \\ Vol. 13 (1) June, 2009}

Saito, K. (1992). Productivity of women farmers in sub-Saharan Africa (Vol. 1) Overview report, population and human resources development department. Washington D.C. World Bank.

UNDP (2005). Human Development Report. Retrieved September 13, 2005 from http://www.ndp.org/hdr 2005.

World Bank (2002). World Bank policy and research bulletin. Vol. II, No. 3, Washington, D.C., World Bank; www.worldbankorg/researWrch/bulletin. 